\title{
Big Book Learning Media Improves the Moral Behavior of Early Childhood
}

\author{
Kadek Dian Ardayani ${ }^{1 *}$, I Made Suariana ${ }^{2}$ \\ 1,2 Prodi Pendidikan Dasar, FIP, Universitas Pendidikan Ganesha, \\ Singaraja, Indonesia \\ `Email: kadekdianardayani@gmail.com¹, imade.suarjana@undiksha.ac.id²
}

\begin{abstract}
Anak-anak masih banyak yang belum memahami terkait dengan perilaku moral, seperti pentingnya mengucapkan terima kasih dan mau saling memaafkan jika melakukan kesalahan. Sehingga, perkembangan moral anak belum berkembang dengan optimal. Penelitian ini bertujuan untuk menghasilkan media Big Book untuk meningkatkan perilaku moral anak. Model pengembangan yang digunakan pada penelitian ini adalah model ADDIE. Model ADDIE terdiri atas analisis (analyze), perancangan (design), pengembangan (development), implementasi (implementation), dan evaluasi (evaluation). Pada penelitian ini dilakukan hanya sampai pada tahap pengembangan. Validasi instrumen media Big Book dilakukan oleh 3 ahli yaitu ahli materi dan ahli media. Pengumpulan data pada penelitian ini menggunakan metode kuisioner untuk menguji media dan materi. Hasil dari penelitian ini diperoleh media Big Book untuk meningkatkan perilaku moral anak usia dini yang dinyatakan valid berdasarkan uji ahli dengan hasil nilai CVR dan CVI yaitu 1,00. Bentuk pengembangan media big book yang dihasilkan adalah sebuah media yang digunakan untuk meningkatkan perilaku moral anak usia dini. Media Big Book ini bisa digunakan oleh guru PAUD untuk meningkatkan perilaku moral anak.
\end{abstract}

Kata Kunci: Media, Big Book, Perilaku Moral

\begin{abstract}
Many children still do not understand moral behavior, such as the importance of saying thank you and being willing to forgive each other if they make mistakes. Thus, the moral development of children has not developed optimally. This study aims to produce Big Book media to improve children's moral behavior. The development model used in this research is the ADDIE model. The ADDIE model consists of analysis (analyze), design (design), development (development), implementation (implementation), and evaluation (evaluation). In this research, only up to the development stage. The validation of the Big Book media instrument was carried out by three experts, namely material experts and media experts. This study collected data using a questionnaire method to test the media and materials. This study obtained the Big Book media to improve the moral behavior of early childhood, which was declared valid based on expert tests with the CVR and CVI scores being 1.00. The form of the development of the big book media produced is a medium used to improve the moral behavior of early childhood. PAUD teachers can use this Big Book media to improve children's moral behavior.
\end{abstract}

Keywords: Media, Big Book, Moral Behavior

\section{INTRODUCTION}

Early childhood is a child in the age 0-6 years. Children are in a golden age because they can develop all aspects of their development. Parents must consider early education, one of which is moral education from an early age to children. The phenomenon of delinquency and violence is often used because moral education in schools, the neighborhood, and even up to college is seen as still failing or less successful. Early childhood has the principle of playing while learning and learning while playing (Anggraini et al., 2020; Apriyanti, 2017; Fatimah \& Rohmah, 2016; Mundia Sari \& Setiawan, 2020). Play is a fun activity, and through fun activities will be able to develop all aspects of development in children, one of which is the development

\footnotetext{
${ }^{*}$ Corresponding author.

Received March 03, 2021; Accepted June 18, 2021; Available online October 25, 2021

This is an open access article under the CC BY-SA license. Copyright $@ 2021$ by Author. Published by Universitas Pendidikan Ganesha.
} 
of moral behavior. Moral behavior results from learning experienced directly from both parents and teachers.

Moral is a measure of the good and bad of a person, both as a person, citizen, and citizen. Moral is the principle of good and bad that exists and is inherent in an individual or person (Abduh \& Taniredja, 2017; Rahelly, 2018; Sulthoni, 2016). Although morals are in the individual, morals are in a system of rules. Moral and morality have a slight difference because morality is a principle of good-bad while morality is a quality of good-bad judgment. Thus, the essence and meaning of morality can be seen from the way individuals who have morals obey and run the rules. At the same time, moral education is education to make human children moral and humane. Thus, in early childhood education, stimulating children's moral development is needed to train children to learn to act by moral education in society (Nisa' et al., 2016; Nuryanto, 2017).

However, the above expectations are very different from the reality found on the ground. Children also often interfere with friends in playing and learning. They do not care about the difficulties and are more concerned with themselves. The author often encounters this kind of phenomenon in Taman Kanak-Kanak Mutiara Singaraja. The problem is encountered when the author makes observations and observations. It can be seen from the attitudes and daily habits of children at school, such as disturbing friends in learning and playing, not like to help, not being used to saying thank you, and not wanting to forgive each other when they make mistakes. It shows that understanding moral behavior is necessary for both parents and children. The understanding possessed by parents will be very helpful in educating their children, while the understanding possessed by children can be applied in the school environment and the community.

Based on the results of observations at Mutiara Kindergarten Singaraja, the results showed that teachers had provided lessons on moral behavior to children. However, it is still very minimal and far from good expectations from selecting methods and the limitations of the learning media that are owned as if. Many children still do not understand moral behavior, such as the importance of saying thank you and being willing to forgive each other if they make mistakes. Thus, the moral development of children has not developed optimally.

Early childhood learning is based not only on the method used but also on various learning media. Media are all forms that are used for the process of distributing information. Learning media are everything, both physical and technical, in the learning process that can help teachers to make it easier to convey learning materials to students to facilitate the achievement of learning objectives that have been formulated (Fauyan, 2019; Munawar \& Suryadi, 2019; Rahmi et al., 2019). Media is a tool that can help the teaching and learning process and clarify the message's meaning so that the teaching objectives can be delivered properly and perfectly. Media contains messages as a learning stimulant and can foster learning motivation so that students do not feel bored and do learning. So that with the media in learning, it is expected that the delivery of learning materials to children will be more effective.

One media that can help increase understanding of moral behavior in children is Big Book media. Big Book is a medium with special characteristics raised, both text and images. It has special characteristics in terms of image shape and color so that in the learning process, there is a shared reading activity between teachers and students. Big book media is a book that has special characteristics that are colorful, interesting pictures, have words that can be repeated, have a predictable plot, and have a rhythmic text plot that can be sung (Mahsun \& Koiriyah, 2019; Ramadhan \& Khairunnisa, 2021; Setiyaningsih \& Syamsudin, 2019). So the Big book is a large book that is colorful and equipped with pictures and text.

In addition to the use of Big Book media, media instruments are also very important. Based on the observations and evaluations, the Big Book learning media instrument used in schools has never been tested for validity and reliability. The use and meaning of the media is less than optimal. The validity and reliability score of an instrument greatly determines the feasibility of the function of the instrument. By using the latest theories, the resulting instrument can accurately assess the target (Inteni et al., 2013; Maulida et al., 2020). The purpose of this research is to produce an appropriate Big Book learning media to improve the moral behavior of early childhood.

\section{METHOD}

This research is Research and Development research. The product developed is the Big Book learning media which includes material on moral behavior. The development design 
used in this research is the ADDIE development model. Analysis, Design, Development, and Implementation. This model is used because the ADDIE model is the most appropriate to develop learning media. In this research, the development carried out is the development of Big Book learning media to improve the moral behavior of Early Childhood in Mutiara Kindergarten Singaraja. The subjects in this study are media experts and material experts. The material expert in question is the lecturer who plays a role in determining whether the material packaged in the Big Book media to improve children's moral behavior is by the level of depth of the material and the truth of the material used or not. At the same time, experts in the media are lecturers or experts who can handle learning media.

This research procedure adopts the ADDIE development model, which is a development model consisting of five stages, namely Analysis, Design, Development, Implementation, and Evaluation. In this study, to collect data, the researchers used the method of observation, interviews, and questionnaires. The instrument used in this study used a questionnaire or questionnaire, which the researcher himself made. The instrument used in this study to produce accurate data is using a Likert scale, very $\operatorname{good}(A)=4, \operatorname{good}(B)=3$, enough $(C)=2$ poor $(D)=1$.

The instrument in this study used a questionnaire given to material experts and learning media experts. The questionnaire will later be given to media experts and material experts. This questionnaire is used to obtain data on product feasibility in the form of numbers as a basis for product revision. As for the grid of instruments used in data collection, they are as follows. The analysis used in this study uses qualitative and quantitative statistical analysis. Qualitative statistical analysis was used to manage data in responses, criticisms, and suggestions from expert reviews, including two lecturers and one principal.

The results of the review were then analyzed by classifying qualitative data in the form of comments and suggestions obtained. The results of the analysis are then used to improve the developed media. Meanwhile, quantitative statistical analysis was used to describe the average score of each expert regarding the developed media. The quantitative statistical data analysis method was chosen to analyze the scores obtained by giving the Big Bok media assessment sheet. The scores obtained are then averaged to determine the validity of the Big Bok media using the Content Validity Ratio (CVR) formula. After identifying each instrument sub-question using the CVR, the next step is to calculate CVI (Content Validity Index). To calculate the average CVI is used from the overall CVR score.

\section{RESULT AND DISCUSSION}

Result

The media validity test uses two experts, including one material expert and one media expert. The Big Book media validity test results are presented in Table 1 and 2.

Table 1. Material Validity Test Results

\begin{tabular}{|c|c|c|c|c|c|c|}
\hline \multirow[b]{2}{*}{ No } & \multirow{2}{*}{$\begin{array}{l}\text { Assessment } \\
\text { Aspect }\end{array}$} & \multirow[b]{2}{*}{ Indicator } & \multicolumn{2}{|c|}{ Experts } & \multirow[b]{2}{*}{ CVR } & \multirow{2}{*}{$\begin{array}{c}\text { Desc } \\
\text { riptio } \\
n\end{array}$} \\
\hline & & & 1 & 2 & & \\
\hline \multirow[b]{2}{*}{1} & \multirow[b]{2}{*}{ Curriculum } & $\begin{array}{l}\text { The suitability of Big Book media } \\
\text { material with children's characteristics }\end{array}$ & $A$ & $A$ & 1,00 & Valid \\
\hline & & $\begin{array}{l}\text { The suitability of the Big Book media } \\
\text { material with the level of child } \\
\text { development achievement (TPPA) }\end{array}$ & B & A & 1,00 & Valid \\
\hline 2 & Purpose & $\begin{array}{l}\text { Big Book media is suitable to support } \\
\text { the improvement of children's moral } \\
\text { behavior }\end{array}$ & $B$ & B & 1,00 & Valid \\
\hline \multirow{3}{*}{3} & \multirow{3}{*}{$\begin{array}{l}\text { Contents } \\
\text { Material Clarity }\end{array}$} & The title matches the material & A & A & 1,00 & Valid \\
\hline & & \multirow{2}{*}{$\begin{array}{l}\text { Neatness of presentation of contents } \\
\text { The clarity of the material in the } \\
\text { picture }\end{array}$} & $B$ & $A$ & 1,00 & Valid \\
\hline & & & $\mathrm{B}$ & B & 1,00 & Valid \\
\hline 4 & Language & $\begin{array}{l}\text { The language used is clear and } \\
\text { simple }\end{array}$ & $B$ & B & 1,00 & Valid \\
\hline \multirow[t]{2}{*}{5} & Motivationi & $\begin{array}{l}\text { Materials can motivate children's } \\
\text { learning }\end{array}$ & $\mathrm{B}$ & A & 1,00 & Valid \\
\hline & \multicolumn{2}{|r|}{ CVI } & & & 1 & Valid \\
\hline
\end{tabular}


Based on the results of the above calculations, obtained a CVR score $=1$ and a CVI score $=1$, it can be said that the material is valid and feasible to use to support the moral development of Early Childhood.

Tabel 2. Hasil Uji Validitas Media

\begin{tabular}{|c|c|c|c|c|c|c|}
\hline \multirow{2}{*}{ No } & \multirow{2}{*}{$\begin{array}{c}\text { Assessment } \\
\text { Aspect }\end{array}$} & \multirow{2}{*}{ Indicator } & \multicolumn{2}{|c|}{ Experts } & \multirow{2}{*}{ CVR } & \multirow{2}{*}{$\begin{array}{l}\text { Descr } \\
\text { iption }\end{array}$} \\
\hline & & & 1 & 2 & & \\
\hline \multirow{3}{*}{1} & \multirow{3}{*}{ Aesthetics } & $\begin{array}{l}\text { The attraction of Big Book } \\
\text { media }\end{array}$ & B & A & 1,00 & Valid \\
\hline & & $\begin{array}{l}\text { Big Bok media size is easy } \\
\text { for children to reach }\end{array}$ & B & B & 1,00 & Valid \\
\hline & & $\begin{array}{l}\text { The suitability of the letters } \\
\text { used }\end{array}$ & B & B & 1,00 & Valid \\
\hline \multirow{6}{*}{2} & \multirow{6}{*}{ Technical } & $\begin{array}{l}\text { Ease of use of Big Bok } \\
\text { media }\end{array}$ & A & A & 1,00 & Valid \\
\hline & & $\begin{array}{l}\text { Practical and easy to use } \\
\text { product }\end{array}$ & A & A & 1,00 & Valid \\
\hline & & $\begin{array}{l}\text { Can be used in the long } \\
\text { term (Not easily damaged) }\end{array}$ & B & A & 1,00 & Valid \\
\hline & & $\begin{array}{l}\text { The product has good } \\
\text { durability }\end{array}$ & B & B & 1,00 & Valid \\
\hline & & $\begin{array}{l}\text { Products are packaged } \\
\text { attractively }\end{array}$ & B & A & 1,00 & Valid \\
\hline & & & & & 1,00 & Valid \\
\hline
\end{tabular}

Based on the results of the above calculations, obtained a CVR score $=1$ and a CVI score $=1$, it can be said that the media is valid and feasible to use to support the moral improvement of early childhood students.

\section{Discussion}

Big Book media development is carried out using the ADDIE model by going through several stages: analysis, design, development, implementation, and evaluation. However, there are not implemented stages, namely implementation, and evaluation. It is due to limited time, energy, resources, and finances.

Analyze stage. At this stage, the analysis of the stages carried out analyzes children's needs and media analysis. Thus, data is obtained to design a learning media that suits the needs and existing problems. Furthermore, the analysis results can be designed using the Big Book media for moral inculcation in group B children at Mutiara Singaraja Kindergarten. The design stage. The Big Book media design is carried out based on the analysis carried out at this stage.

In the development stage, the implementation of media development is adjusted to the design that has been made. After the Big Book media has been developed, the next process is an assessment by two experts. Then the validity data were obtained from the assessment that the two experts had assessed. The CVR score was 1.00 and the CVI was 1.00 with eight statements on the material instrument and eight on the media instrument.

Media big book is a large book and has a large writing. Big books are large learning media, and their writing is also raised. The big book is categorized as one of the children's books used to learn to read and write in the early stages. The developed big book contains material suitable for children and can motivate children's learning. In addition, this big book also contains character values to improve children's moral behavior.

Learning the development of moral behavior must start from early childhood, because with children having good moral behavior, of course, children will also behave in good morals and know the values that apply and must be obeyed, with children accustomed to good behavior, children will continue to behave well until grow up later. In moral development, early childhood still learns a lot about various things in their lives. Children learn to observe, recognize and act according to their hearts. Children learn various events in their lives. From these events, the child will receive positive and negative influences. Empathy for others will also develop if the child gets guidance and direction from adults (Supeni, 2015; Yuliana \& Wurinta, 2020). For this reason, guidance and direction are needed from an early age so that this good behavior remains embedded into adulthood 
The results of this study are in line with research that found that the use of big books is very effective in improving learning outcomes (Ramadhan \& Khairunnisa, 2021). Then the research found that the big book media developed according to media experts was very good in terms of the feasibility of content, language, presentation, graphics, and cover aspects (Setiyaningsih \& Syamsudin, 2019). In addition, the assessment of the big book media in the initial field test, main field test and expanded field test has a valid Aiken validity. The limitations of this study are that the Big Book media development results cannot be tested on students. Due to the Covid-19 emergency, the authors only produce media that are suitable for use. Therefore, this study has not provided information about the effectiveness and efficiency of using Big Book media for moral inculcation in group B children at Mutiara Singaraja Kindergarten.

\section{CONCLUSION}

The development of the Big Book media for teaching early childhood morals resulted in media used to instill early childhood morals. PAUD teachers can use this Big Book media for moral development for Early Childhood. The Big Book media instrument has been tested for validity so that the Big Book media is appropriate and feasible to use. The suggestions given are as follows. Other researchers can use this development research to reference existing problems, especially development for media, and this research can be continued at the implementation stage by carrying out experimental research.

\section{REFERENCES}

Abduh, M., \& Taniredja, T. (2017). Penanaman Nilai-Nilai Sila li Pancasila Pada Peserta Didik Kelas V Sekolah Dasar. Journal of Moral and Civic Education, 1(1), 36-49. https://doi.org/10.24036/885141202017118.

Anggraini, W., Nasirun, M., \& Yulidesni, Y. (2020). Penerapan Strategi Pemecahan Masalah dalam Meningkatkan Kemampuan Kognitif pada Anak Kelompok B. Jurnal IImiah Potensia, 5(1), 31-39. https://doi.org/10.33369/jip.5.1.31-39.

Apriyanti, H. (2017). Pemahaman Guru Pendidikan Anak Usia Dini Terhadap Perencanaan Pembelajaran Tematik. Jurnal Obsesi: Jurnal Pendidikan Anak Usia Dini, 1(2), 111117. https://doi.org/10.31004/obsesi.v1i2.22.

Fatimah, D. F., \& Rohmah, N. (2016). Pola Pengelolaan Pendidikan Anak Usia Dini di PAUD Ceria Gondangsari Suowono Jawa Tengah: Tahun Pelajaran 2015-2016. Manageria: Jurnal Manajemen Pendidikan ISlam, 247-273. https://doi.org/10.14421/manageria.2016.12-05.

Fauyan, M. (2019). Developing Interactive Multimedia Through Ispring on Indonesian Language Learning with The Insights of Islamic Values in Madrasah Ibtidaiyah. Al Ibtida: Jurnal Pendidikan Guru MI, 6(2), 177. https://doi.org/10.24235/al.ibtida.snj.v6i2.4173.

Inteni, K. A. S., Candiasa, I. M., \& Suarni, N. K. (2013). Pengembangan instrumen tes objektif pilihan ganda yang diperluas berbasis web untuk mata pelajaran TIK kelas XI SMAN di Kabupaten Karangasem. Jurnal Penelitian Dan Evaluasi Pendidikan, Vol 3(5). http://119.252.161.254/e-journal/index.php/jurnal_ep/article/view/1039/787.

Mahsun, M., \& Koiriyah, M. (2019). Meningkatkan Keterampilan Membaca melalui Media Big Book pada Siswa Kelas IA MI Nurul Islam Kalibendo Pasirian Lumajang. Bidayatuna: Jurnal Pendidikan Guru Mandrasah Ibtidaiyah, 2(1), 60. https://doi.org/10.36835/bidayatuna.v2i1.361.

Maulida, I., Dibia, I. K., \& Astawan, I. G. (2020). The Development of Social Attitude Assessment Instrument and Social Studies Learning Outcomes Grade IV on Theme of Indahnya Keragaman di Negeriku. Indonesian Journal Of Educational Research and Review, 3(1), 12. https://doi.org/10.23887/ijerr.v3i2.25823.

Munawar, A., \& Suryadi, A. (2019). Pengembangan Media Pembelajaran Sejarah Indonesia Berbasis Videoscribe Materi Kerajaan Islam Di Jawa Kelas X Tahun Ajaran 2018 / 2019 Di SMA Negeri 3 Salatiga Pendidikan merupakan komponen pent- kepribadian yang lebih baik. Menurut Tri- dengan perubahan . 7(2), 174-184. https://journal.unnes.ac.id/sju/index.php/ijhe/article/view/36436.

Mundia Sari, K., \& Setiawan, H. (2020). Kompetensi Pedagogik Guru dalam Melaksanakan Penilaian Pembelajaran Anak Usia Dini. Jurnal Obsesi : Jurnal Pendidikan Anak Usia Dini, 4(2), 900-912. https://doi.org/10.31004/obsesi.v4i2.478. 
Nisa', T. F., Karim, M. B., \& Mayangsari, D. (2016). Membangun Karakter Anak Usia Dini melalui Pembelajaran Math Character. PEDAGOGIA: Jurnal Pendidikan, 5(2), 113. https://doi.org/10.21070/pedagogia.v5i2.241.

Nuryanto, S. (2017). Peningkatan Nilai-Nilai Karakter dengan Metode Mendongeng Cas Cis Cus di BA Aisyiyah Kaponan 2 Ponorogo. Journal of Nonformal Education and Community Empowerment, 3(1), 11-20. https://doi.org/10.15294/jne.v3i1.8732.

Rahelly, Y. (2018). Implementasi Kurikulum 2013 Pendidikan Anak Usia Dini (Paud) Di Sumatera Selatan. JPUD - Jurnal Pendidikan Usia Dini, 12(2), 381-390. https://doi.org/10.21009/JPUD.122.21

Rahmi, M. S. M., Budiman, M. A., \& Widyaningrum, A. (2019). Pengembangan Media Pembelajaran Interaktif Macromedia Flash 8 Pada Pembelajaran Tematik Tema Pengalamanku. International Journal Of Elementary Education, 3(2), 178-185. https://doi.org/10.23887/ijee.v3i2.18524.

Ramadhan, N., \& Khairunnisa. (2021). Efektivitas Penggunaan Media Pembelajaran Big book Subtema Indahnya Keberagaman Budaya Negeriku. Tarbiyah Wa Ta'lim: Jurnal Penelitian Pendidikan Dan Pembelajaran, 8(1), 49-60. https://doi.org/10.21093/twt.v8i1.3208.

Setiyaningsih, G., \& Syamsudin, A. (2019). Pengembangan Media Big Book Untuk Meningkatkan Kemampuan Literasi Anak Usia 5-6 Tahun. Scholaria: Jurnal Pendidikan Dan Kebudayaan, 9(1), 19-28. https://doi.org/10.24246/j.js.2019.v9.i1.p19-28.

Sulthoni, S. (2016). Penanaman Nilai-Nilai Budi Pekerti Di Sekolah Dasar. Sekolah Dasar: Kajian Teori Dan Praktik Pendidikan, 25(2), 100-108. https://doi.org/10.17977/um009v25i22016p100.

Supeni, S. (2015). Pengembangan Model Internalisasi Pendidikan Karakter Pancasila Pada Guru Pendidikan Anak Usia Dini Siti. Cakrawala Pendidikan, 1(1), 118-127. https://doi.org/10.21831/cp.v1i1.4182.

Yuliana, A. R., \& Wurinta, A. R. (2020). Manajemen Strategi Pembelajaran dalam Membentuk 9 Pilar Karakter di Playgroup MILAS. Jurnal PG-PAUD Trunojoyo : Jurnal Pendidikan Dan Pembelajaran Anak Usia Dini, 7(1), 37-46. https://doi.org/10.21107/pgpaudtrunojoyo.v7i1.6833. 